\title{
Socio-economic deprivation and health outcomes in Ialomița County (Romania)
}

\author{
Ana-Maria Taloş \\ University of Bucharest, Romania
}

Several health researchers have emphasised the effects of socio-economic factors on population health outcomes. Many studies have been demonstrating the relationship between socio-economic conditions and individual health, as they have stated that deprived population are more likely to have a higher rate of morbidity and mortality due to different diseases. This study examines the association between socioeconomic deprivation and health outcomes among the population from urban and rural communities in Ialomiţa County (Romania). The research is based on statistical and spatial analysis, using indicators related to socio-economic deprivation (economic status index, housing endowment index, education level index and) and indicators related to health outcomes. Preliminary results showed the expansion of deprived areas, overlapping areas with precarious population health, generally areas with high incidence of respiratory and digestive diseases, high mortality due to infectious diseases.

Key Words: socio-economic deprivation, composite indices, health inequalities, population health, health outcomes.

Article Info: Received: March 2, 2017; Revised: October 1, 2017; Accepted: November 3, 2017 ; Online: November 25, 2017.

\section{Introduction}

Health is an important dimension of society, health issues being frequently associated with determinants as the physical and social environment, population health behaviour, healthcare access and quality care. Usually, the social determinants of health are considered the key-problem in shaping territorial differences, as the social environment could be associated with several aspects which

\section{Correspondence address}

Address: University of Bucharest, Faculty of Geography, Department of Human Geography, Av. Nicolae Balcescu, no. 1, Bucharest, 010041, Romania.

Phone: 0040213143508 | Email: ana.talos@geo.unibuc.ro

(C)2017 Human Geographies; The authors

(c) (i) This work is licensed under a

Creative Commons Attribution 4.0 International License. DOI:10.5719/hgeo.2017.112.8 
imply social composition, institutions or individual behaviours. Social determinants generally affect the population health conditions, being associated with high incidence of certain diseases or precarious health status at the spatial level, resulting in territorial inequities and inequalities.

It is widely recognised the relationship between health outcomes with premature deaths as well as with socioeconomic, cultural and environmental factors, living and working conditions, lifestyle (Benzeval et al., 1995). Territorial variations in health outcomes could be correlated with differences in the social composition of the population (Sloggett \& Joshi, 1998), although there are also environmental and individual influences (Duncan et al., 1998).

Deprivation has been defined by Townsend (1987) as a state of 'observable and demonstrable disadvantages relative to the local community to which an individual belongs'. According to Townsend, these disadvantages could have the social or material origin as social fragmentation, poverty, illiteracy, deprivation being closely linked to well-being and health. Townsend proposed for the first time an index to evaluate the socio-economic deprivation among the population, by considering different socioeconomic variables: unemployment rate, housing density, individuals without a car and a house in property. After Townsend research, a wide range of studies have proposed, using different methods and techniques to construct deprivation indices: Bell, Schuurman \& Hayes (2007); Cabrera Barona et al. (2015); Lalloue et al. (2013); Pasetto, Sampaolo and Pirastu (2010), Zamfir, Dumitrache et al (2015) etc.

In order to estimate the relative deprivation of an area, some demographic, social and economic characteristics have also been considered in different studies. According to the approach, the availability and data reliability, complex indices have been constructed by taking into account various indicators related to economic status, education level or living conditions. Haase and Pratschke (2012) considered the major socioeconomic inequalities as education level, unemployment, professional classes, and lone rates, while for Schuurman et al. (2007), income, education, employment and family structure prevail.

In many of these studies, some common elements could be found: education, income, employment, living conditions, representing essential components associated with social and economic determinants of population health. Socioeconomic deprivation could be associated with areas characterised by social exclusion limited access to clean water, household overcrowding, unemployment, lack of formal education etc. (Havard et al., 2008) and precarious population health outcomes (Boyle, Gatrell \& Duke-Williams, 2001).

Using also multi-criteria or participatory approaches, different studies tried to demonstrate the relationship between socioeconomic conditions and health outcomes in various places, based on quantitative or qualitative indicators. According to Marmot \& Bell (2012), proper living conditions and decent income are associated with a fewer number of diseases, many illnesses being registered among the poor than the wealthy population. According to other studies, socioeconomic deprivation has been correlated with increasing rate of hospitaluse and higher health care costs (Zhao et al., 2011). In the same way, income is considered a significant determinant of multidimensional deprivation in Vietnam, as earnings can be spent on a wide range of goods and services to satisfy and fulfil other basic human needs (Mahadevana \& Hoang, 2016). 
A number of studies have assessed the direct relationship between illness and inadequate urban housing conditions, poor infrastructure or overcrowding being associated with precarious health (Galea \& Vlahov 2005). Also, people living in wealthy neighbourhoods have a lower risk of contracting diseases compared to people living in poor ones (Pampalon \& Raymond, 2000). A good correlation between long-term illness and deprivation has also been demonstrated in England and Wales (Haynes \& Gale, 1999). Various methods were established to calculate composite indices, and there are several alternatives in producing aggregated indicators. However, the reliability and validity of data used are the most important as the different type of data could be combined (OCDE, 2008).

'Social deprived' areas are defined by a combination of census measures that include high unemployment, low-status occupation, overcrowded living conditions, low share of homeowners and cars, and high proportions of vulnerable people living alone (Watt \& Sheldon, 1993).

Starting from these studies, this paper attempts an estimation of relative deprivation in a plain area, Ialomița County, close to the capital city (Bucharest), by using a complex index according to the availability of data.

The present research aims to analyse the relationship between population health outcomes and socio-economic deprivation, by using a number of indicators related to economic status, education level and housing conditions. These indicators were correlated with different health outcomes. The precarious health status of the population, the economic decline registered in the last period (being one of the poorest counties in Romania), as well as the expansion of unemployment and social instability (Taloş, 2017), were reasons in selection Ialomița County as the study area. An important limitation of the study is the lack of various categories of data at the micro territorial level, the reduced availability and reliability of data, influencing the selection of indicators which were considered in constructing the composites indices.

\section{Methodology}

In order to analyse the relationship between socio-economic deprivation and population health outcomes in Ialomiţa County, statistical and spatial analysis have been used. To evaluate the socio-economic deprivation, three important components were considered: economic status, education level and housing endowment, based on various indicators. Using available data from the 2011 Census of Population of Romania, a complex index of socio-economic deprivation has been calculated. The complex index of socio-economic deprivation resulted from the standardization and aggregation of the three composite indices: economic status index, education level index and housing endowment index (Zamfir, Dumitrache et al., 2015) (Table 1).

The economic status index was based on (1) percentage of the unemployed population, (2) percentage of the inactive population, (3) percentage of the economically dependent population and (4) percentage of the retired population. The indicators considered for the analysis of the housing endowment index are important in determining the comfort degree and the quality of life of the 
Table 1. Composite indices of socio-economic deprivation index

\begin{tabular}{|c|c|}
\hline Components & Subcomponents \\
\hline \multirow{4}{*}{$\begin{array}{l}\text { economic } \\
\text { status index } \\
\text { (lec) }\end{array}$} & unemployed (\% of active population ) \\
\hline & inactive population ( $\%$ of total population) \\
\hline & economic dependents (\% of total population) \\
\hline & retirees (\% of employed population) \\
\hline \multirow{4}{*}{$\begin{array}{l}\text { housing } \\
\text { endowment } \\
\text { index } \\
\text { (Ih) }\end{array}$} & habitation density (the ratio of persons per room) \\
\hline & $\begin{array}{l}\text { dwellings without access to drinking water from the public system } \\
\text { (\% of total dwellings) }\end{array}$ \\
\hline & households without indoor toilet (\% of total dwellings) \\
\hline & person/dwelling (the ratio of persons per dwelling) \\
\hline \multirow{4}{*}{$\begin{array}{l}\text { education } \\
\text { level index } \\
\text { (le) }\end{array}$} & $\begin{array}{l}\text { population that does not have any level of formal education or } \\
\text { instruction ( } \% \text { of total population) }\end{array}$ \\
\hline & illiterates (\% of total population) \\
\hline & women with secondary education (\% of total women) \\
\hline & women with higher education (\% of total women) \\
\hline
\end{tabular}

inhabitants: (1) the ratio of persons per room (overcrowding), (2) percentage of households without access to drinking water from the public system, (3) percentage of households without bathrooms, (4) the ratio of persons per household.

The education level index took into account a set of four socio-economic indicators: (1) percentage of the population without any level of formal education or instruction, (2) percentage of the illiterate population, (3) percentage of women with secondary education and (4) percentage of women with higher education.

The values of the socio-economic deprivation index were between 0 and 1 , the higher values being associated with higher deprivation.

Bivariate correlation has been performed (Pearson correlation) between composite indices of socio-economic deprivation index, in order to specify the strength and direction of the relationship between variables.

Correlations between socio-economic deprivation index and each of the three composite indices has been conducted (economic status index, housing endowment index, education level index). As the significance level must be less than 0.001 , statistically significant correlations are between education level index and housing endowment index $(\mathrm{r}=0,69, \mathrm{df}=64, \mathrm{p}<0,001)$, housing endowment index and socio-economic deprivation index $(r=0,82, \mathrm{df}=64$, $\mathrm{p}<0,001)$, socio-economic deprivation index and education level index $(r=0,85$, $\mathrm{df}=64, \mathrm{p}<0,001)$, socio-economic deprivation index and economic status index $(\mathrm{r}=0,67, \mathrm{df}=64, \mathrm{p}<0,001)$ (Table 2). There is a significant relationship between the three composite indices and socio-economic deprivation index, enabling that unemployment, living conditions and education could be considered as socioeconomic variables for the present study.

Pearson correlation has also been used to show the relationship between socio-economic deprivation and health outcomes (morbidity due to digestive and respiratory diseases, mortality due to infectious diseases and tuberculosis). Data related to health outcomes have been provided by Ialomița Public Health Directorate and Ialomița Directorate of Statistics. The territorial inequalities related to deprivation and health outcomes have been evidenced by using an open source program Quantum GIS 2.8.4. 
Table 2. Correlation between composite indices of socio-economic deprivation index

\begin{tabular}{|c|c|c|c|c|c|}
\hline & & $\begin{array}{l}\text { Economic } \\
\text { status index }\end{array}$ & $\begin{array}{l}\text { Housing } \\
\text { endowment } \\
\text { index }\end{array}$ & $\begin{array}{l}\text { Education } \\
\text { level index }\end{array}$ & $\begin{array}{l}\text { Socio-economic } \\
\text { deprivation } \\
\text { index }\end{array}$ \\
\hline \multirow{3}{*}{$\begin{array}{l}\text { Economic } \\
\text { status index }\end{array}$} & $\begin{array}{l}\text { Pearson } \\
\text { Correlation }\end{array}$ & 1 & $.284^{*}$ & $.289^{*}$ & .670 \\
\hline & Sig. (2-tailed) & & .021 & .019 & .000 \\
\hline & $\mathrm{N}$ & 66 & 66 & 66 & 66 \\
\hline \multirow{3}{*}{$\begin{array}{l}\text { Housing } \\
\text { endowment } \\
\text { index }\end{array}$} & $\begin{array}{l}\text { Pearson } \\
\text { Correlation }\end{array}$ & $.284^{*}$ & 1 & $.686^{* *}$ & $.823^{*}$ \\
\hline & Sig. (2-tailed) & .021 & & .000 & .000 \\
\hline & $\mathrm{N}$ & 66 & 66 & 66 & 66 \\
\hline \multirow{3}{*}{$\begin{array}{l}\text { Education } \\
\text { level index }\end{array}$} & $\begin{array}{l}\text { Pearson } \\
\text { Correlation }\end{array}$ & $.289 *$ & $.686^{* *}$ & 1 & $.855^{*}$ \\
\hline & Sig. (2-tailed) & .019 & .000 & & .000 \\
\hline & $\mathrm{N}$ & 66 & 66 & 66 & 66 \\
\hline \multirow{3}{*}{$\begin{array}{l}\text { Socio- } \\
\text { economic } \\
\text { deprivation } \\
\text { index }\end{array}$} & $\begin{array}{l}\text { Pearson } \\
\text { Correlation }\end{array}$ & $.670^{* *}$ & $.823^{* *}$ & $.855^{* *}$ & $1^{* *}$ \\
\hline & Sig. (2-tailed) & .000 & .000 & .000 & \\
\hline & $\mathrm{N}$ & 66 & 66 & 66 & 66 \\
\hline
\end{tabular}

\section{Results and discussion}

The assessment of socio-economic deprivation outlines significant territorial inequalities, as the values of the socio-economic deprivation index $(I d)$ varying from 0.144 to 0.895 , emphasising several deprived areas. In the present study, a deprived area is associated with high rate of unemployment and illiteracy, limited access to basic services and facilities (safe drinking water, sewerage, flush toilets). The variations of $I d$ values resulted from the different influence of composite indices.

\section{Economic status}

Values of economic status index highlight territorial inequalities particularly as a consequence of high unemployment in many rural localities, unemployment rate exceeding 10 or $15 \%$ and more than $12 \%$ of the active population are unemployed (Figure 1).

It has been already suggested that unemployment is more reliable and updatable indicator of social deprivation than the composite indices for small areas generally (Haynes et al., 1996). Unemployment indicates an inconsistency on the labour market, and the highest values are registered in poor and underdeveloped areas. The high share of inactive people leads to imbalance the local economy, as there are not enough active people to provide income, retirement fee, allowances etc.

In the same way, there is a statistical relationship between health outcomes and unemployment, due to different processes: on one hand, people with illness have a higher unemployment probability than people with good health (Arrow, 1996) and, on the other hand, that health status deteriorating while being unemployed due to stress caused by this unhappy life event (Kessler et al., 1987). Economically deprived areas are located in the east part (between Fetești and Țăndărei) and central part (around Căzăneşti city) of Ialomița County, overlapping areas with a high unemployment rate, a high share of retired 
population and a significant percentage of the economically dependent population. The reduced number of working places indicate a vulnerable economic system that easily transposes into deprivation.

Population from rural areas are particularly facing great difficulties in finding employment due to the low level of education or qualification, but on the other hand, there are few investments in the rural area, and a reduced working places offer. For the unemployed people, health problems can come along with the stress and with the limited amount of money available in case of health issues (Figure 1). In a county with $53.9 \%$ of the population living the rural area and $16.5 \%$ representing seniors, the ageing population is an important element to consider in analysing socio-economic deprivation. In many localities from Ialomița County, over $40 \%$ of the population are economically dependent. This aspect could be associated with a higher rate of morbidity and mortality in affected areas (Figure 1).

\section{Housing endowment}

Housing endowment index also reveals territorial inequalities, deprived areas from this point of view being located in the west (rural localities near Urziceni city), central (rural localities around Căzănești city) and east part of the county (rural localities between Țăndărei and Fetești).

Poor housing conditions could be associated with personal problems, like adopting unhealthy behaviours, because of the stress brought by housing difficulties, affordability and overcrowding places (Pollack \& Lynch, 2009). Moreover, crowded conditions are also linked with different health problems: respiratory infections, household accidents or infectious diseases (Bashir, 2002).

Variations of housing endowment index outline also difference in living conditions due to overcrowding, difficult access to safe drinking water and absence of facilities such as flush toilets and sewerage. Rural areas are the most disadvantaged as the higher values of the index are in rural localities, especially those from the east part of the county, and the local population is exposed to

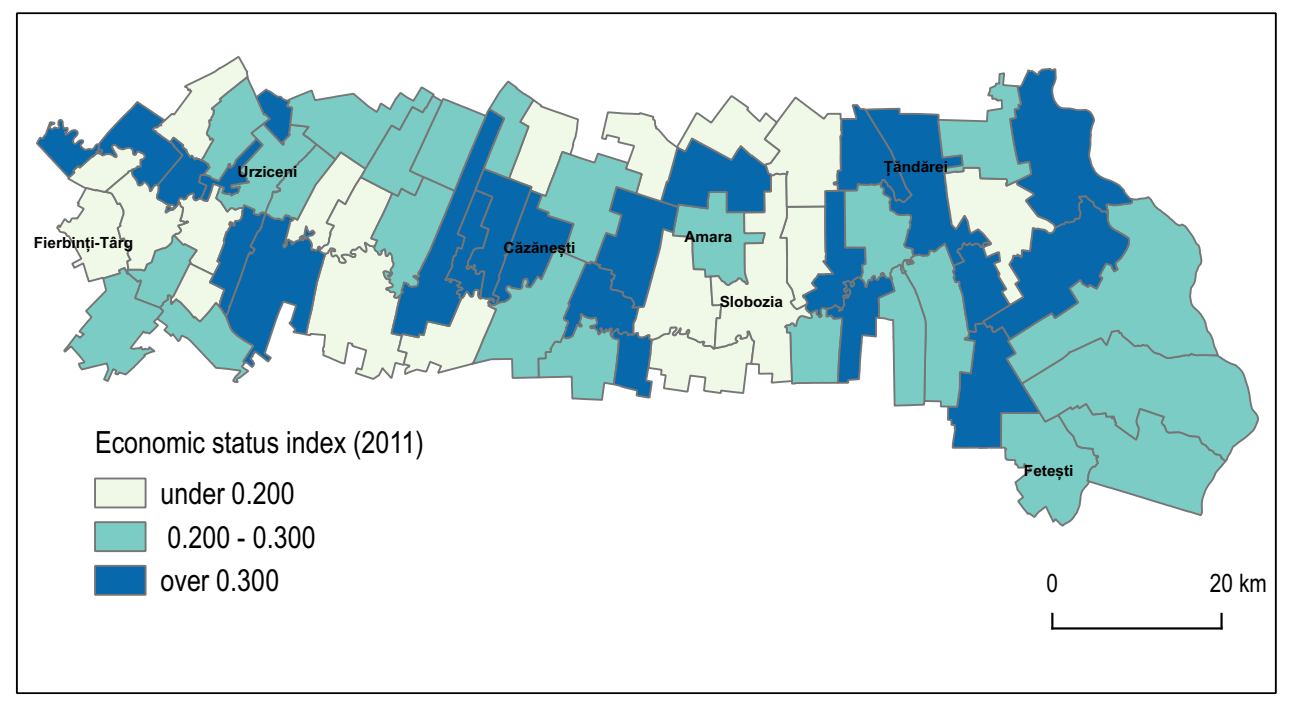

Figure 1. Economic status (2011) 
various diseases (Figure 2). Deprived areas overlap almost the whole county, excepting four cities (Slobozia, Urziceni, Amara and Fetești), generally many of the dwellings have no water supply $(76.25 \%)$ or inside bathrooms $(79.65 \%)$, increasing the risk of infectious, respiratory or digestive system diseases (Figure 4).

\section{Education level}

Education level is another important determinant of socio-economic deprivation, as education was identified in several studies as an indicator of deprived areas and health outcomes: the higher the proportion of illiterate people, the increased risk of chronic or infectious diseases (Braveman et al., 2010). The higher the proportion of women with secondary and higher education, the higher the literacy potential of their children and the lower is the risk of precarious hygiene (Nagahawatte \& Goldenberg, 2008). Education usually shows a relationship with self-rated health such that those with the highest education have the best health and those with lowest education have the worst health. But socioeconomic gradients, including education, must be contextualized within social circumstances (Pearson, 2008). Education became a gradient in the range of health status, disability or chronic conditions, as those with less education have slightly worse health and the best health outcomes are for those with the highest education. That is why, persons who have completed more years of education have better health compared to those who have fewer years of schooling (Braveman et al., 2010).

The territorial analysis highlights differences among Ialomita County population by education level and residence: high rate of illiterate population $(3.97 \%)$, deficiency of population that has graduated a school $(7.13 \%)$ and a low share of women with secondary and high education (37\%), mainly in the rural areas (Figure 3). The maximum values of the indicators considered for the education index are recorded in Bărbulești, a village close to Urziceni city: $33.18 \%$ is represented by population without graduated school, $27.6 \%$ are

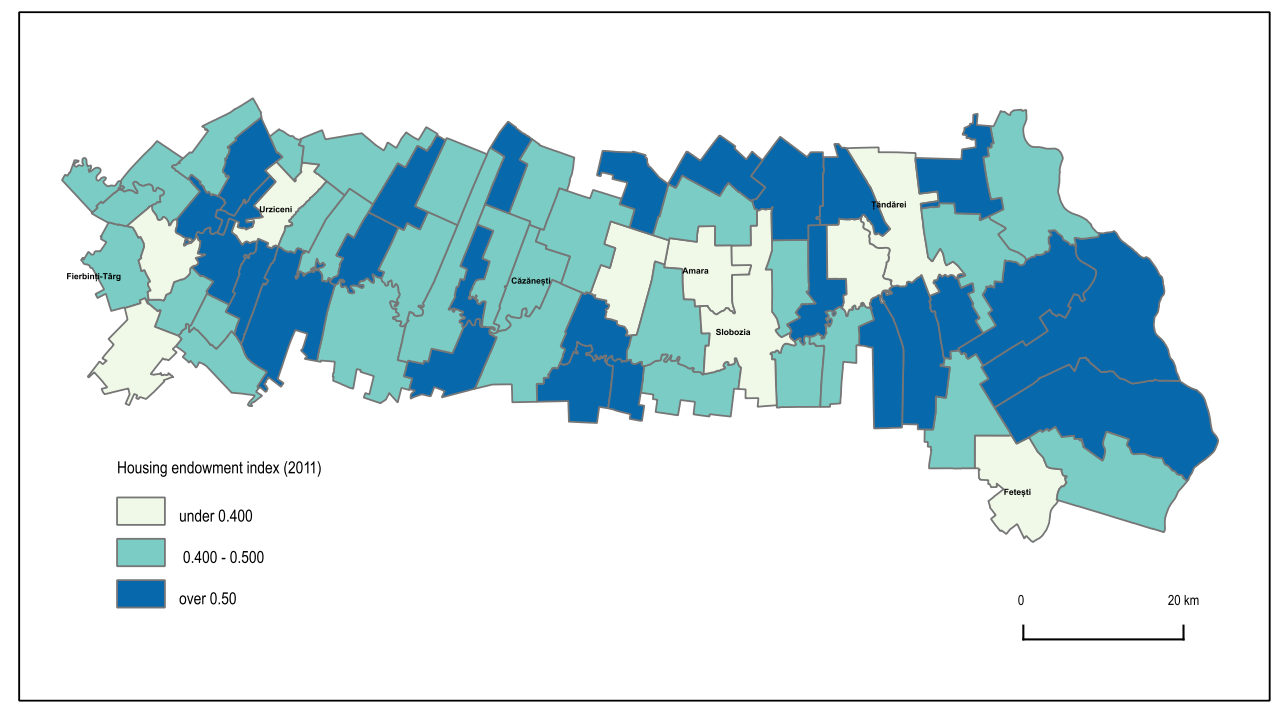

Figure 2. Housing endowment (2011) 
illiterate, there are no women with superior education and $7.37 \%$ of women have secondary education. Generally, the education level index is relatively high across the study area, with averages exceeding 0.250 (Figure 3).

\section{Socio-economic deprivation}

High unemployment rates, increased death rates and negative deprivation scores in rural areas outline the presence of disadvantaged people with poor health (Fearn, 1987). Deprivation is a phenomenon that mostly affects the remote areas from Ialomița County, where the unemployment rate is high $(16.47 \%)$, the share of inactive population surpasses $51.79 \%$ and percentage of the illiterate population represents $3.97 \%$ (according to insse.ro, 2011). The most deprived areas are located in the central (around Căzănești city) and east part of the county (between Tăndărei and Fetești), including a number of 52 localities and affecting around of 50,000 inhabitants.

The results reflect issues related to lack of basic infrastructure and services, deficiencies in providing drinkable water, lack of facilities (sewerage, bathrooms - $78 \%$ have no flush toilets), overcrowding, poor access to healthcare services.

While at the national level the socio-economic deprivation index records average value of 0.383 (Zamfir, Dumitrache et al., 2015), in Ialomița County the situation is worse, the average values surpassing 0.430. Cities as Slobozia, Urziceni, Fetești and Amara are less confronting with issues as low education level, poor housing conditions and unemployment as well as rural localities surrounding these cities where the population has to access to education, working places and facilities from the urban area (Figure 4).

Areas recording the highest values of socio-economic deprivation index are also registering higher values of all composite index. However, there are localities where housing endowment index exceeded average values, contributing significantly to the increase of socio-economic deprivation index $(I d)$ value, namely to worsening of the situation. For example, many little towns as Fierbinți-Târg (in the eastern extremity of the county), which don't have urban

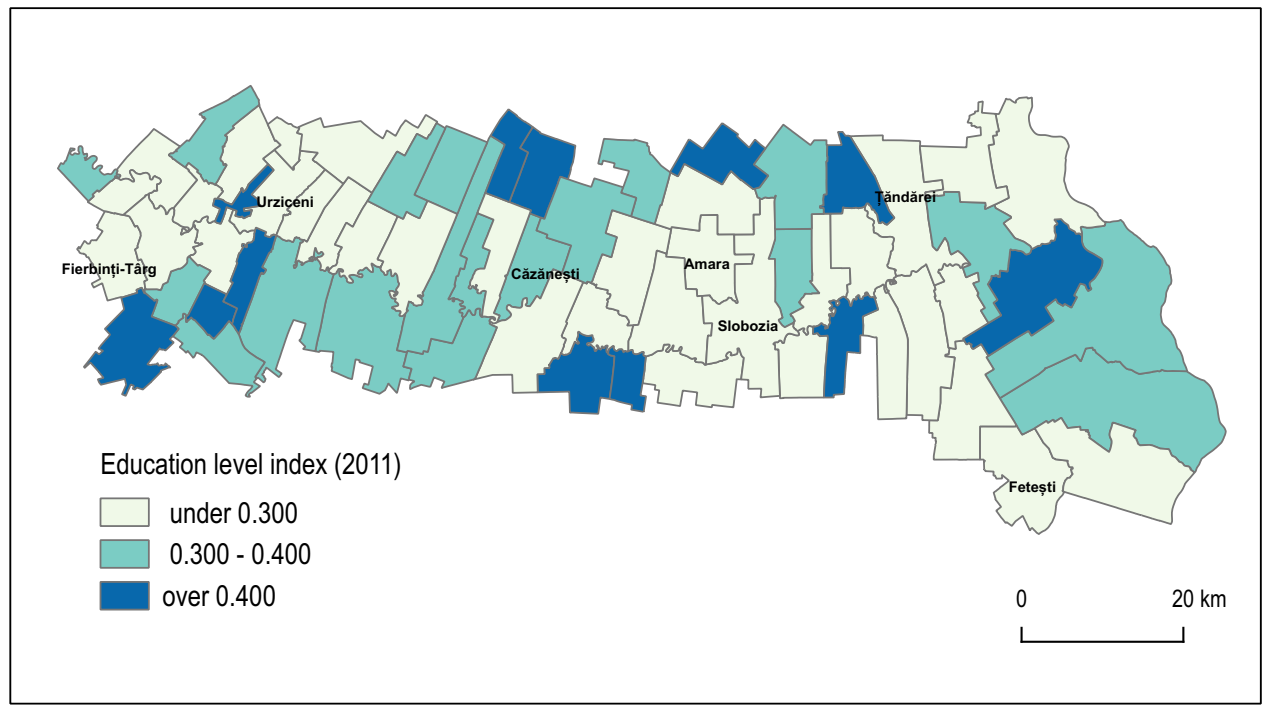

Figure 3. Education level (2011) 
characteristics or facilities, being included in the category of 'towns' during the communist period just for balancing the urban-rural gap. Communities like Bărbulești and Roșiori, located in the west part of the county, recorded higher values of education level index (Ie). This situation is based on cultural reasons that determine an increased rate of illiterate population and decreased the share of women without secondary or superior education.

There are also areas where the economic status index (Iec) has the largest contribution, as there is a considerable share of the population of working age that is unemployed and also a great part of them are socially assisted. This happens particularly in the east part of the county, in localities as Țăndărei and Gheorghe Doja, where over $15 \%$ of the active population is unemployed as there are few working places available (Figure 4).

\section{Health outcomes}

Economic and social deprivation has an important contribution to mortality, as this contribution increases gradually with the level of deprivation. The variation in deprivation is closely linked to variation in premature mortality (Pampalon et al., 2009).

In Ialomița County, mortality due to digestive and respiratory system diseases, as well as infectious diseases is higher than other regions of the country. Higher rate of mortality due to these diseases are registered in both rural and urban areas, but the values of these indicators are significantly higher in deprived areas located in a central and eastern part of the county.

One of the major problem related to these deprived areas is represented by the largest extent of infectious diseases, particularly in the eastern part of the county in localities situated at a great distance to the nearest city (Figure 5).

Also, the morbidity due to respiratory and digestive system diseases is higher in these deprived areas, overlapping regions with poor economic status, improper living conditions and precarious education level. Generally, the deprived areas from the centre and east part of the county are overlapping

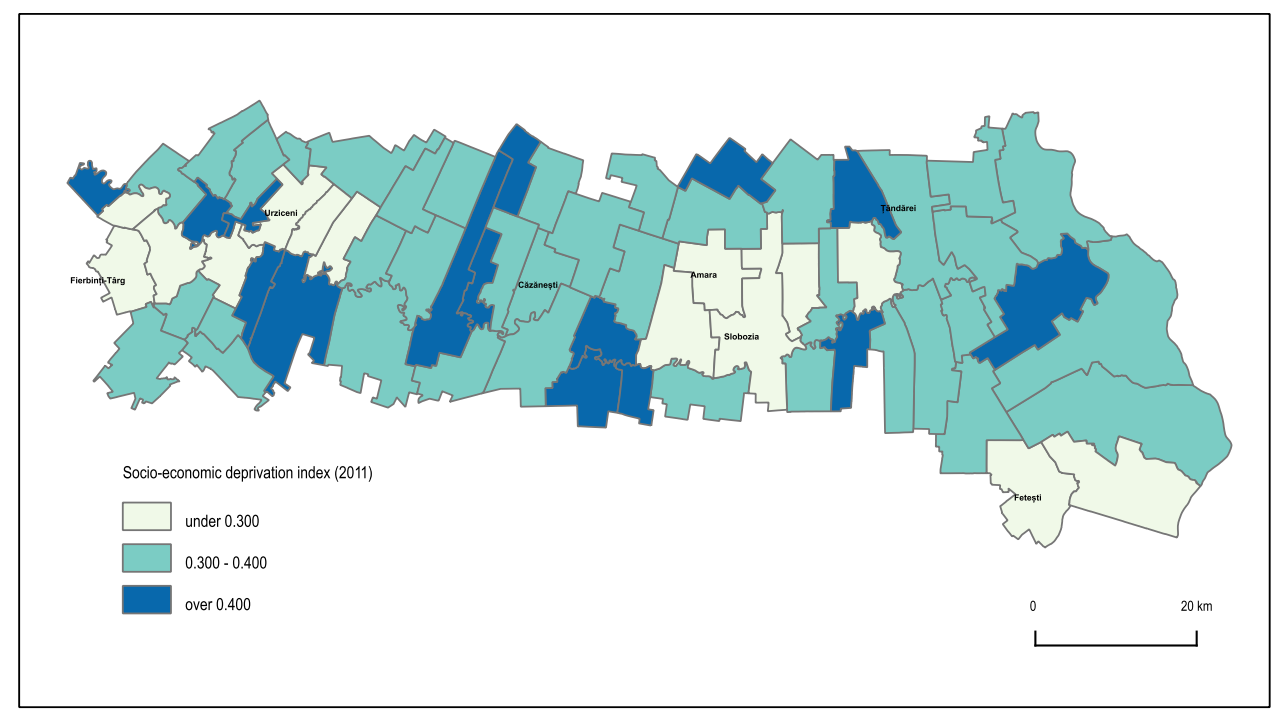

Figure 4. Socio-economic deprivation (2011) 
areas with precarious population health outcomes (high incidence of respiratory and digestive diseases, and high level of mortality particularly due to infectious, respiratory or digestive diseases).

Pearson correlation between socio-economic deprivation index components and specific mortality and morbidity show significant associations. Only the significance level under 000.1 are considered, meaning that statistically significant correlations are between mortality due to infectious diseases and mortality due to tuberculosis $(\mathrm{r}=0,85, \mathrm{df}=64, \mathrm{p}<0,001)$, morbidity due to respiratory diseases and economic status index $(\mathrm{r}=0,32, \mathrm{df}=64, \mathrm{p}<0,001)$, morbidity due to respiratory diseases and housing endowment index $(r=0,41$, $\mathrm{df}=64, \mathrm{p}<0,001)$, morbidity due to digestive diseases and housing endowment index $(r=0,27, \mathrm{df}=64, \mathrm{p}<0,001)$.

There is no significant correlation between mortality due to infectious diseases and economic status index, too. There is a poor correlation between education level and mortality due to respiratory diseases. The reduced data availability could explain these inconsistency. Social and economic deprivation explained more of the variation in inequalities in health outcomes. Better level education, decent living conditions and higher economic status could improve population health outcomes (Figure 6).

\section{Conclusions}

The study aimed to analyse the relationship between population health outcomes and socioeconomic deprivation in Ialomița County, identifying territorial inequalities. Deprived areas overlap regions with high incidence of respiratory and digestive diseases and high level of mortality due to infectious, respiratory or digestive diseases.
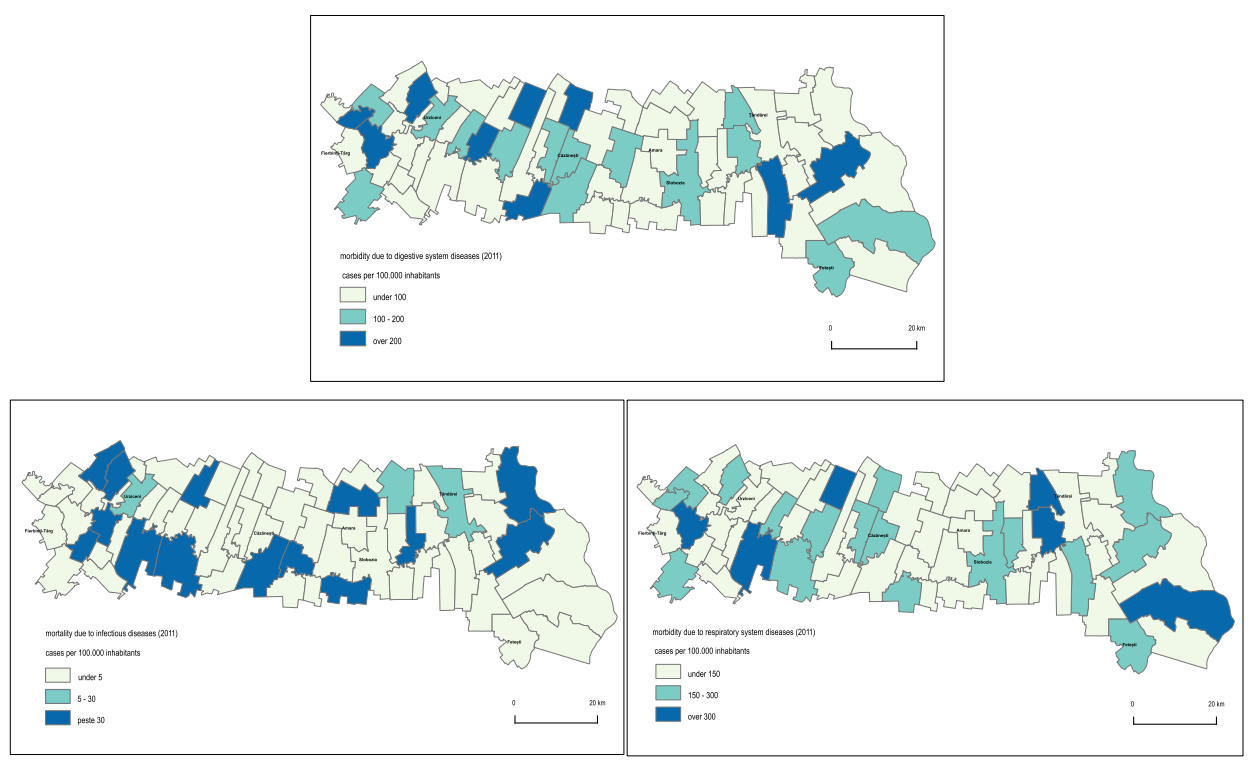

Figure 5. Specific mortality and morbidity patterns 


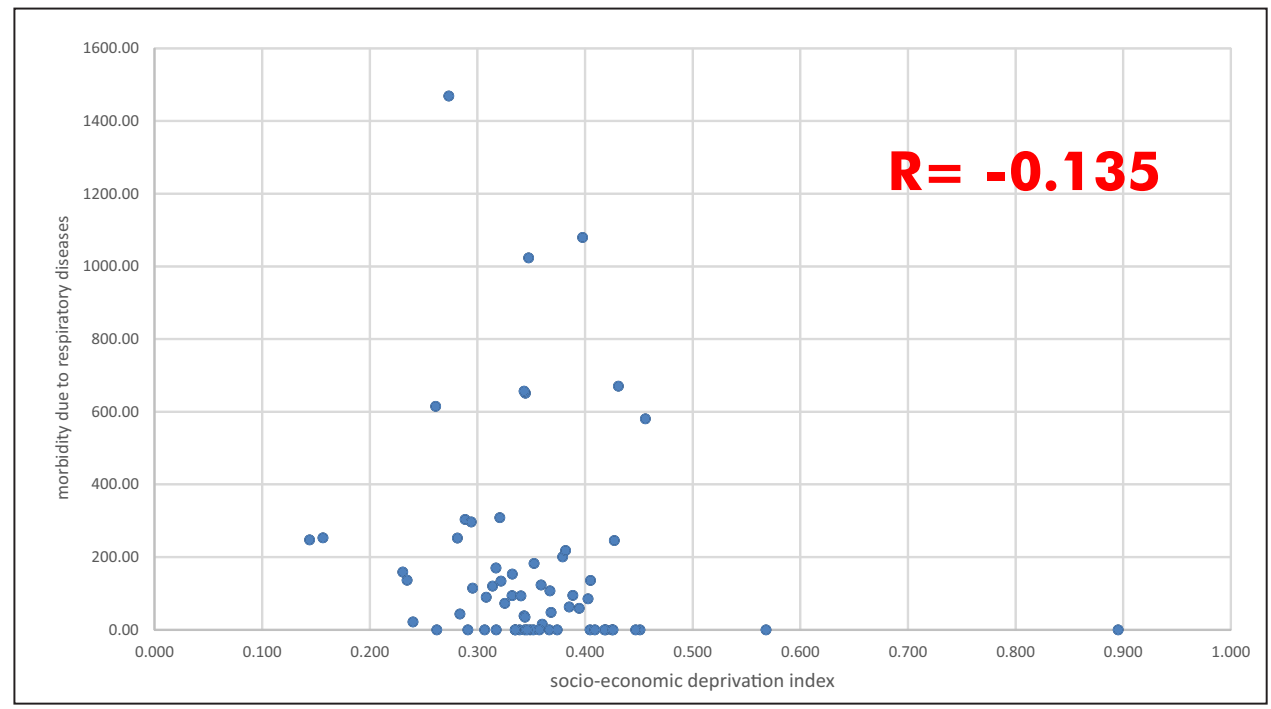

Figure 6. Correlation between morbidity due to respiratory diseases and socio-economic deprivation

There are significant differences between urban and rural areas regarding socio-economic deprivation. Preliminary results showed that economic status, living conditions and education level have an influence on population health outcomes, being often associated with good or poor health outcomes.

The study findings indicated that unemployment, poor housing conditions and low education level were associated with higher mortality and morbidity due to various diseases. The results demonstrated associations between health and socio-economic deprivation, mainly those related to low income or unemploy-ment, poor access to facilities as flush toilets and sewerage, lack of formal education or illiteracy.

\section{References}

Arrow, J.O. (1996), 'Estimating the influence of health as a risk factor on unemployment: a survival analysis of employment durations for workers surveyed in the German Socio-Economic Panel (1984-1990)', Social Science and Medicine, no. 42, pp. 1651-1659.

Bashir, S. (2002), 'Home is where the harm is: inadequate housing as a public health crisis', Public Health, no. 92, pp. 733-8.

Bell, N., Schuurman N. and Hayes M.V. (2007), 'Using GIS-based methods of multicriteria analysis to construct socio-economic deprivation indices', International Journal of Health Geographics, vol. 6, no.17.

Benzeval, M., Judge, K. and Whitehead, M. (1995), Tackling Inequalities in Health: An Agenda for Action, London, King's Fund.

Boyle, P., Gatrell, A. and Duke-Williams, O. (2001), 'Do area-level population change, deprivation and variations in deprivation affect individual-level selfreported limiting long-term illness?', Social Science छ Medicine, no. 53, pp. 795799. 
Braveman, P.A., Cubbin, C., Egerter, S.,Williams, D.R. and Pamuk, E. (2010), 'Socioeconomic disparities in health in the United States: what the patterns tell us', American Journal of Public Health, no.100 (S1), pp. S186-S196.

Cabrera Barona, P., Murphy, T., Kienberger S. and Blaschke, T. (2015), 'A multi-criteria spatial deprivation index to support health inequality analyses', International Journal of Health Geographics, vol. 14, no. 11.

Duncan, C., Jones, K. and Moon, G. (1998), 'Context, composition and heterogeneity: using multilevel models in health research', Social Science and Medicine, no. 46 , pp. $97-117$.

Fearn, R. (1987), 'Rural health care: a British success or a tale of unmet need?', Social Science and Medicine, no. 24, pp. 263-274.

Galea, S and Vlahov, D. (2005), 'Urban health: evidence, challenges and directions', Public Health, no. 26, pp. 1-25.

Haase, T. and Pratschke, J. (2012), 'The 2011 pobal HP deprivation index for small areas', Dublin.

Havard, S., Deguen, S., Bodin, J., Louis, K., Laurent, O and Bard, D. (2008), 'A small-area index of socioeconomic deprivation to capture health inequalities in France', Social Science E' Medicine, no. 67, pp. 2007-2016.

Haynes, R., Gale, S., Lovett, A. and Bentham, G. (1996), 'Unemployment rate as an updatable health needs indicator for small areas', Journal of Public Health Medicine, no. 18, pp. 27-32

Haynes R., Gale S. (1999), 'Mortality, long term illness and deprivation in rural and metropolitan wards of England and Wales', Health and Place, no.5, p. 301-312.

Kessler, R.C., House, J.S. and Turner, J.B. (1987), 'Unemployment and health in a community sample', Journal of Health and Social Behavior, no. 28, pp. 51-59.

Lalloué, B., Monnez, J.M., Padilla, C., Kihal, W., Le Meur, N., Zmirou-Navier D. and Deguen, S. (2013), 'A statistical procedure to create a neighborhood socioeconomic index for health inequalities analysis', International Journal for Equity in Health, vol. 12, no. 21, pp. 1-11.

Mahadevana, R. and Hoang, V. (2016), 'The nexus between poverty and deprivation in Vietnam', Journal of Policy Modeling, no. 38, pp. 290-303.

Marmot, M. and Bell, R. (2012), 'Fair society, healthy lives', Public Health, no. 126 , pp. 4-10.

Nagahawatte, N.T. and Goldenberg, R.L. (2008), 'Poverty, maternal health, and adverse pregnancy outcomes', Annals of the New York Academy of Science, no. 1136 , pp. 80-85.

OECD (2008), Handbook on Constructing Composite Indicators, Paris, OECD.

Pampalon, R. and Raymond, G. (2000), 'A deprivation Index for health and welfare planning in Quebec', Chronic Diseases in Canada, vol. 21, no. 3, pp. 104113.

Pampalon, R., Hamel, D., Gamache, P. and Raymond G. (2009), 'A deprivation index for health planning in Canada', Chronic diseases in Canada, vol. 29, no. 4, pp. 178-191.

Pasetto, R., Sampaolo, L. and Pirastu, R. (2010), 'Measures of material and social circumstances to adjust for deprivation in small-area studies of environment and health: review and perspectives', Annual First Super Sanita, vol. 46, no. 2, pp. 185-197. 
Pearson, J.A. (2008), 'Can't buy me whiteness: new lessons from the titanic on race, ethnicity and health', Du Bois Review, vol. 5, no. 1, p. 27.

Pollack, C.E. and Lynch, J. (2009), 'Health status of people undergoing foreclosure in the Philadelphia region', American Journal of Public Health, no. 99, pp. 1833-1839.

Schuurman, N, Bell, N, Dunn, JR. and Oliver, L. (2007), 'Deprivation index, population health and geography: an evaluation of the spatial effectiveness of indices at multiple scales', Journal of Urban Health, vol. 84, no. 4, pp. 591-603.

Sloggett, A. and Joshi, H. (1998), 'Deprivation indicators as predictors of life events 1981-1992 based on the UK ONS longitudinal study', Journal of Epidemiology and Community Health, no. 52, p. 228-233.

Taloş, A.M. (2017), 'Population lifestyle and health in Ialomița County (Romania)', Romanian Journal of Geography, vol. 61, no. 1, pp. 79-86.

Townsend, P. (1987), 'Deprivation', Journal of Social Policy, vol. 16, pp. 25-46.

Watt, I.S. and Sheldon, T.A. (1993), 'Rurality and resource allocation in the UK', Health Policy, no. 26, pp. 19-27.

Zamfir, D., Dumitrache, L., Stoica, I.V. and Vîrdol, D. (2015), 'Spatial inequalities in health care provision in Romania: millestones for territorial sustainable development', Carpathian Journal of Earth and Environmental Sciences, vol. 10, no. 3, pp. 177-188.

Zhao, Y., You, J, Guthridge, SL. and Lee, AH. (2011), 'A multilevel analysis on the relationship between neighbourhood poverty and public hospital utilization: is the high Indigenous morbidity avoidable?', BMC Public Health, no. 11, p. 737. 